مقايسه توليد Fاما- دكالاكتون در سويه طبيعى و جهش يافته مخمر lipolytica

\author{
فرشاد درويشى ז،ا و آرمين خير اللهى ميدانى'

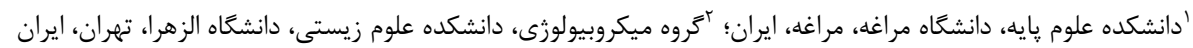

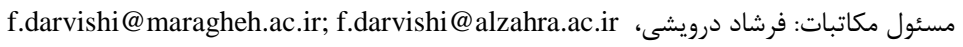

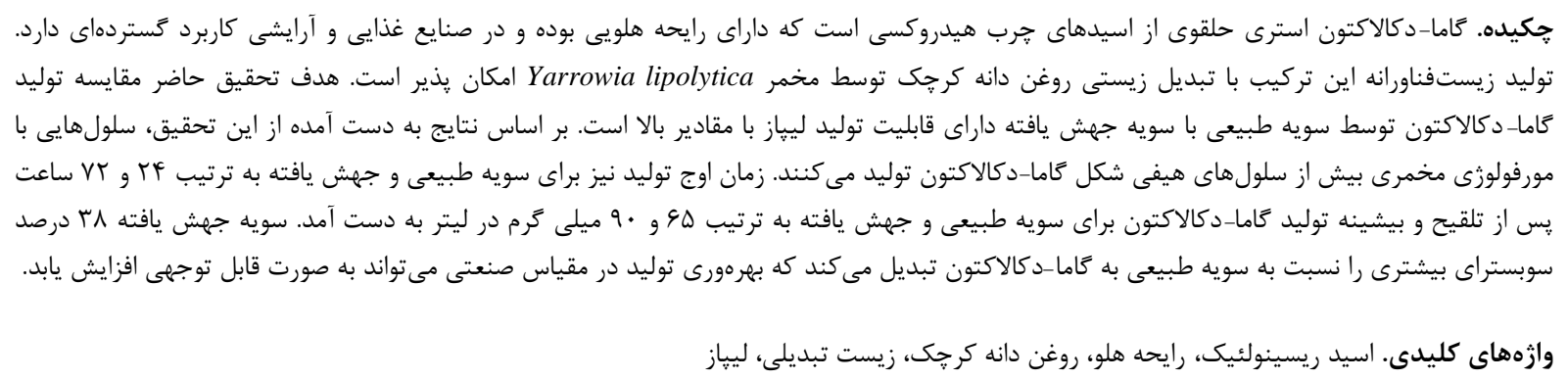

\title{
A comparison of the production of gamma-decalactone in wild-type and mutant strains of Yarrowia lipolytica
}

\section{Farshad Darvishi $^{1,2}$ \& Armin Kheirollahi Meidani ${ }^{1}$}

${ }^{1}$ Faculty of Science, University of Maragheh, Maragheh, Iran; ${ }^{2}$ Department of Microbiology, Faculty of Biological Sciences, Alzahra University, Tehran, Iran

Correspondent author: Farshad Darvishi, f.darvishi@maragheh.ac.ir; f.darvishi@alzahra.ac.ir

\begin{abstract}
Gamma-decalactone, an intramolecular 4-hydroxydecanoic acid ester, has a peach-like aroma and is widely used in the food and cosmetics industries. The biotechnological production of this compound is possible via biotransformation of castor seed oil by the yeast Yarrowia lipolytica. This study aimed to compare the production of gamma-decalactone by wild-type strain with that in a mutant strain producing lipase in high amounts. It was found that cells with yeast-like morphology produce more gamma-decalactone than hyphae-like cells. The maximum production of gamma-decalactone by wild-type and mutant strains was $65 \mathrm{mg} / \mathrm{L}$ after $24 \mathrm{~h}$ of inoculation and $90 \mathrm{mg} / \mathrm{L}$ after $72 \mathrm{~h}$ of inoculation, respectively. The mutant strain converts $38 \%$ more substrate into gamma-decalactone than the wild-type strain, therefore, it could significantly increase the productivity of industrial-scale production of gamma-decalactone.
\end{abstract}

Key words. biotransformation, castor seed oil, lipase, peach-like aroma, ricinoleic acid 


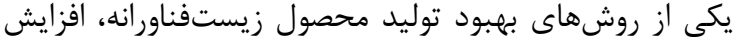
دسترسى سلولها به سوبسترا است كه اين كار بار با افزايش هيدروليز سوبسترا به كمك آنزيمها امكانيذير است ( Braga et al., 2012; Darvishi et al., 2009 شده سلولى (به صورت آزاد يا تثبيت شده) نيز مىتوانند به إنه

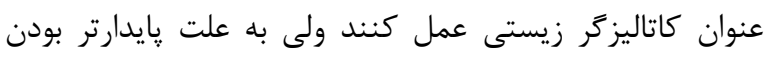

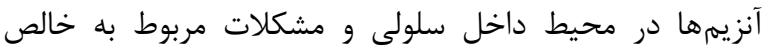
سازى و كنترل مسير واكنش، استفاده از سلول كامل براى انجام

فرايند كزينه مناسبترى است (Liese et al., 2006). روشهاى مختلف مهندسى زنتيك به منظور افزايش توليد

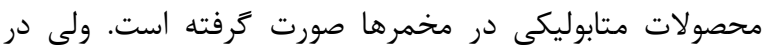

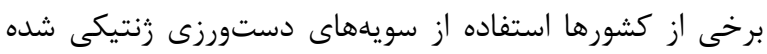

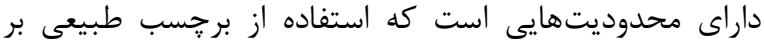

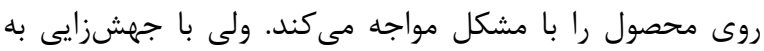

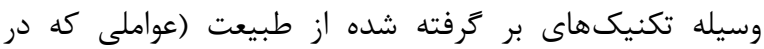

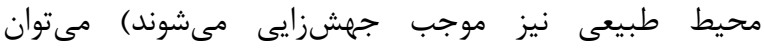
سويههايى ايمن ايجاد كرد كه محصولات توليد شده توسط آنها طبيعى شناخته مىشوند (Zeng et al., 2015). در اين تحقيق از سويه جهشيافته مخمر lipolytica

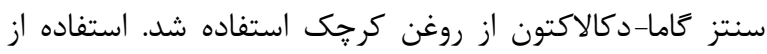

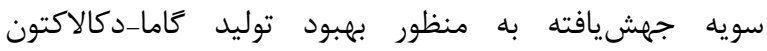
رويكردى است كه باعث حفظ برجسب طبيعى روى محصولات

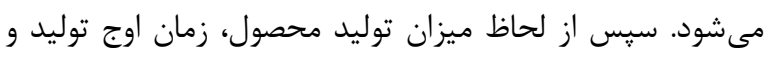

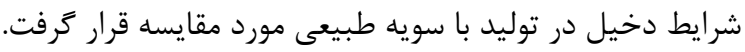

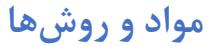

ميكروار كانيسمهاى مورد استفاده

سويه استاندراد مورد استفاده در اين تحقيق

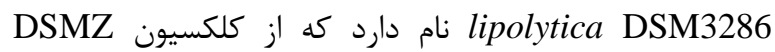
آلمان خريدارى شده است. سويه جهشبافته مورد استفاده Yarrowia lipolytica U6 حاصل از DSM3286 است كه توسط درويشى و همكاران در

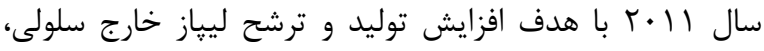

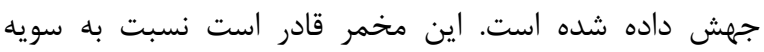

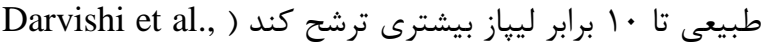

مقدمه منشاء استفاده از مواد معطر در زندگى انسان به آغاز تاريخ بشر باز مى

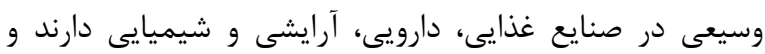

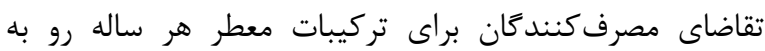
افزايش است (Braga \& Belo, 2016; Vandamme, 2003). با توجه به كاهش كرايش مصرف كنند استان به تركيبات شيميايى،

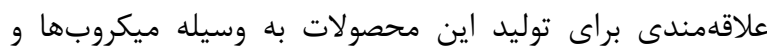

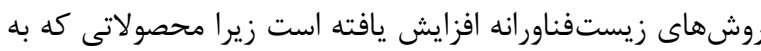

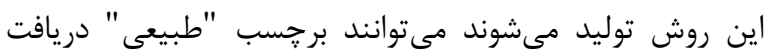
كنند (Gatfield, 1988; Vandamme, 2003).

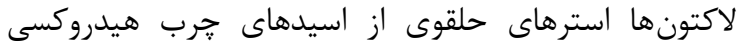
هستند كه به علت داشتن عطرهاى ميوهاى، كرهاى و شيرين آندائ كاربردهاى صنعتى فراوانى دارند (Maga \& Katz, 1976).

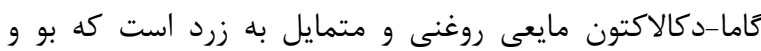

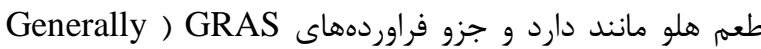
Arctander, ) طبقهبندى مىشود (Recognize As Safe هنايع (1969; Siek et al., 1971 صنايع غذايى به منظور توليد نوشدنىهايى با رايحه هلو، انبه، توتفرنگى و همجنين در شكلات سازى است ( Malajowicz et .al., 2020

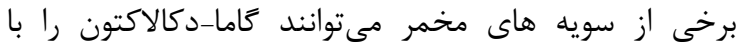
تبديل زيستى اسيد ريسينولئيك كه جزء اصلى تشكيل دهنده روغن كرجك است، توليد كنند ) Braga, 2014; Darvishi \& Chen, 2018 ). نخستين تحقيقات در زمينه توليد زيستفناورانه

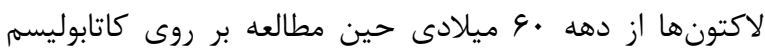
اسيدهاى خرب هيدروكسيله توسط اركانيسمهاى مختلف آغاز شد كه در تحقيق مذبور ززارشى مبنى بر توليد لاكتون توسط ميد سويه مخمر كانديدا ارائه شد (Okui et al., 1963). يكى از مخمرهايى كه به لطف آنزيمهاى مسير بتااكسيداسيون و لييازهاى خارج سلولى خود قادر به تبديل زيستى

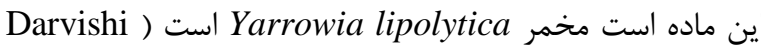
Yarrowia .et al., 2018; Farbood \& Willis, 1985

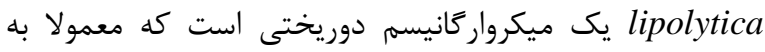
شكل تك سلول يا هيف رشتهاى ديده مىشود. اين مخمر ايمن بوده و تاكنون براى كاربردهاى متفاوت صنعتى از جمله تهيه

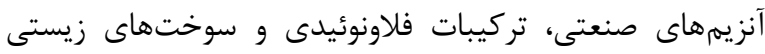

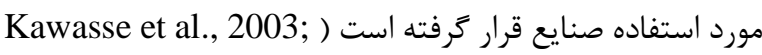
.(Liu et al., 2021; Marsafari et al., 2020 
جشمى تعداد مخمرها در واحد مشخصى از حجم شمرده و سيس با اعمال ضريب (معادله ()، تعداد سلول در يك ميلىليتر

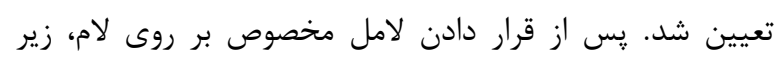
ميكروسكوף نورى عمل شمارش انجام يذيرفت. در صورتى زياد بودن تراكم سلولى، نمونهها با ضريب مشخصى رئى رقيق شدند

(Mather \& Roberts, 1998)

\section{معادله}

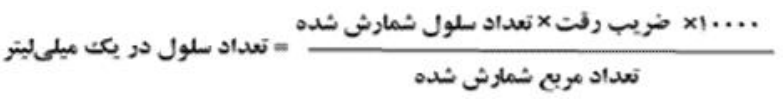

تهيه منحنى استاندارد بر اساس غلظتهاى مختلف عَاماـدكالاكتون

به منظور تعيين غلظت كاما_دكالاكتون در نمونههاى مجهول، بايد از منحنى استاندارد اين ماده استفاده كرد. براى رسم اين

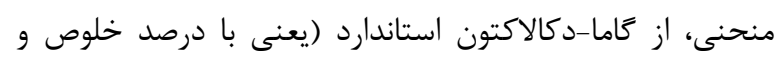

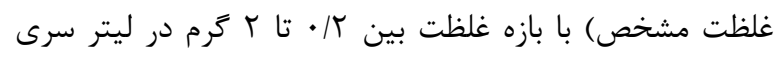

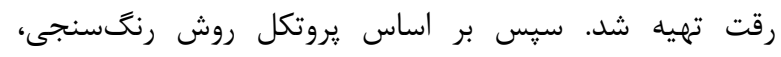

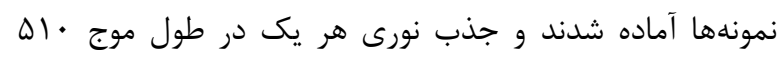
نانومتر ثبت شد. سيس بر اساس نمودار حاصل از برازش سرى ئى رقت و جذب، رابطه رياضى حاكم بين اين دو عامل استخراج شد. سيس جذب نورى به دست آمده از نمونههاى مجهول در رابطه حاصل قرار داده شد و غلظت آنها تعيين كرديد.

\section{سنجش توليد كاما-دكالاكتون}

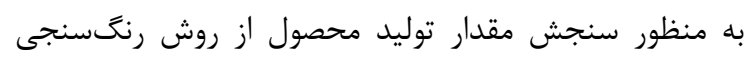

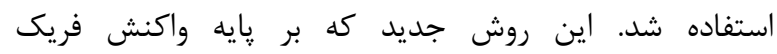
هيدروكسامات توسعه داده شده است، قادر است مقادير كاماــ دكالاكتون را به صورت كمى و سريع شناسايى كند. نمونهها به

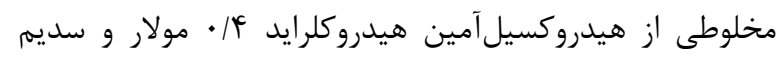

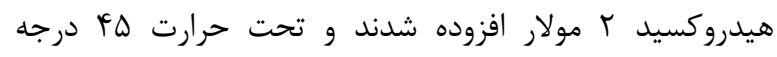
سانتى

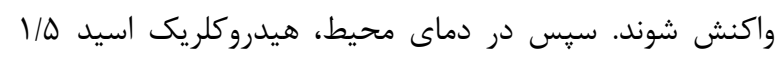

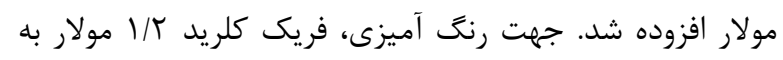

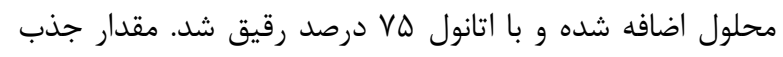
نورى محلول حاصل توسط دستخاه اسيكتروفتومتر (Uل) Zhao et (Shimadzu

.(al., 2014

محاسبه درصد بازيابى كَاما_دكالاكتون از محيط كشت به منظور بررسى كارايى اين روش در شناسايى مقادير كامادكالاكتون موجود در محيط كشت مورد استفاده در اين تحقيق يس از تخمير، ابتدا غلظت محصول توليد شده در سه مد نمونه
محيط كشت YPD جامد به منظور رشد، ذخيرهسازى و جداسازى تك كلنىهاى Yarrowia lipolytica مورد استفاده قرار گرفت. از محيط كشت YPD مايع نيز به عنوان محيط ييشكشت (مايه تلقيح) جهت آماده سازى سلولهاى مخمرى براى ورود به محيط تبديل زيستى استفاده شد. به منظور تهييه

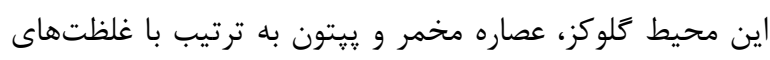

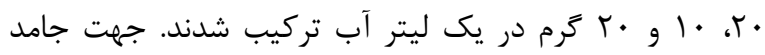
سازى محيط به ازاى هر ليتر از تركيب ذكر شده، · ب ترم آثار

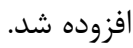

\section{محيط كشت تبديل زيستى}

به منظور توليد كاما-دكالاكتون و تامين ديكر نيازهاى زيستى سلولها از محيط كشت تغيير يافته بر پايه YPD استفاده شد.

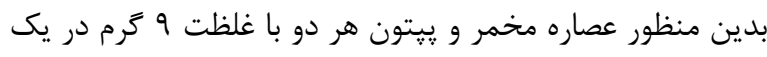

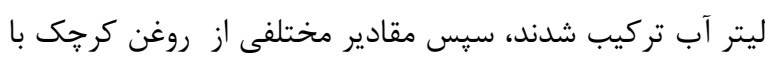

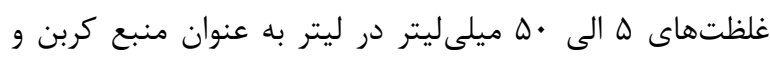
ييشماده تبديل زيستى به محيط افزوده شد. آماده سازى محيط توليد محصول

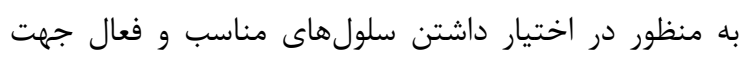
توليد كاما-دكالاكتون و يكنواخت بودن تعليقه (سوسيانسيون)

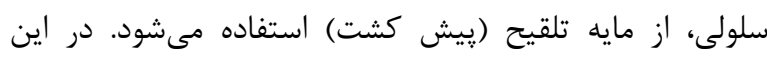
تحقيق YPD مايع به عنوان مايع تلقيح مورد استفاده قرار

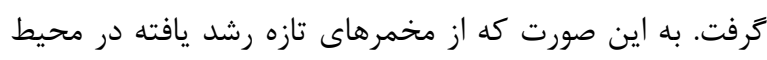
جامد (در دماى qج درجه سانتى

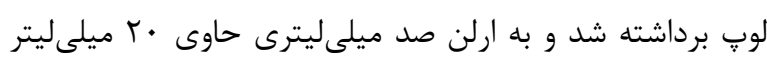

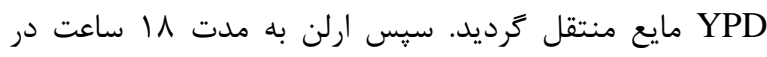

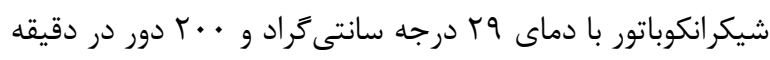

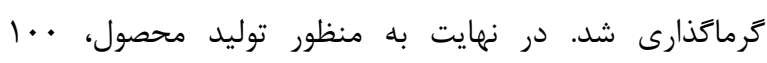

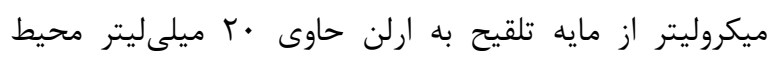

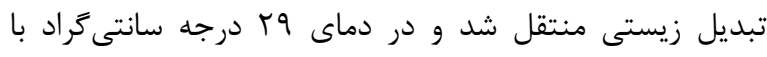

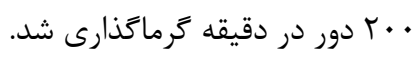

بر رسى ريختشناسى سلولى و مشاهده كلنى ها

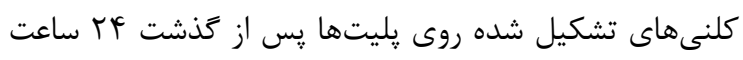

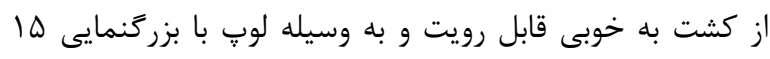

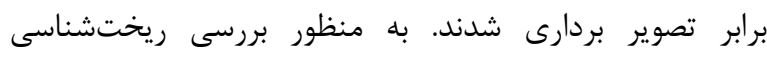

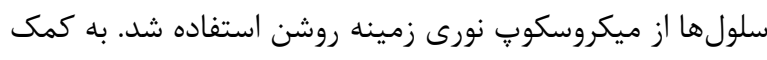
دوربين مخصوص تصويربردارى از ميكروسكوب، تصاوير نمونهها تهييه شد. روش اندازهيرى رشد سلولى نلى بدين منظور از روش شمارش مستقيم سلولها رست استفاده شد.

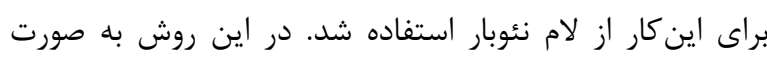


روى 9 تنظيم شد (Moradi et al., 2016). سيس ميزان رشد

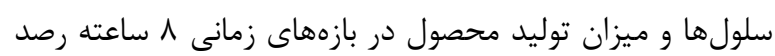

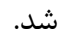

دادههاى حاصل وارد نرمافزار

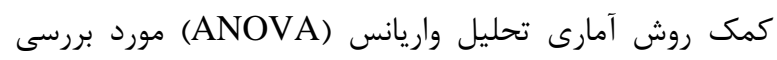
قرار كرفتند.

\section{نتايج}

ابتدا به مشاهده و مقايسه كلنىهاى دو سويه مخمرى رشد كرده

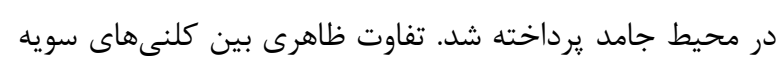
جهشيافته و طبيعى به وضوح قابل تشخيص است. سويه طبيعى دانى

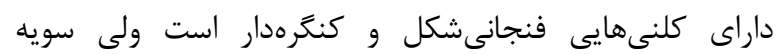

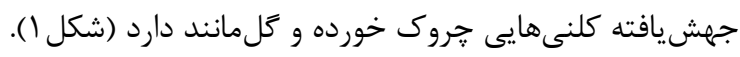

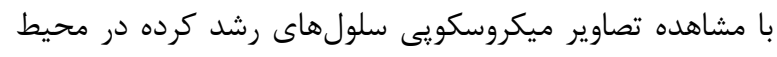

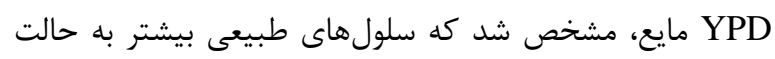

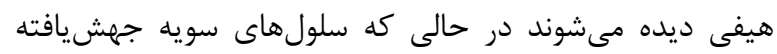
بسيار به ندرت تشكيل هيف داده و و با مورفولوزى مخمرى ديد ديده

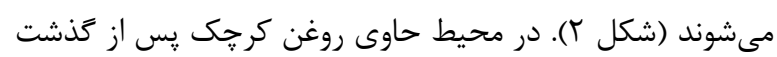

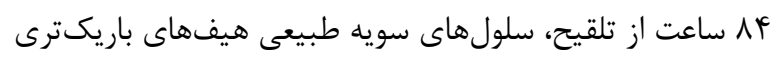

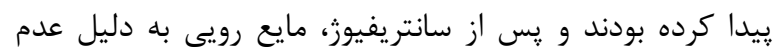

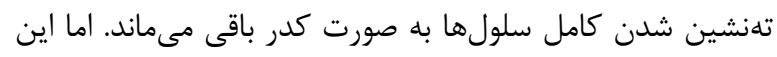

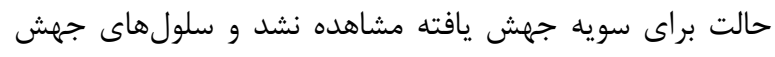

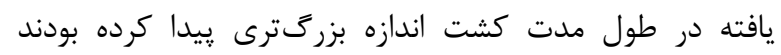

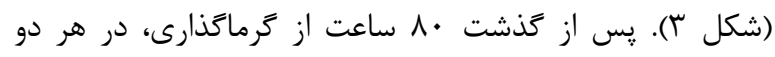

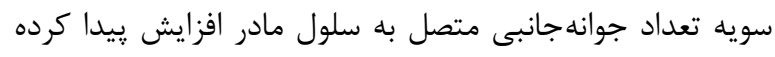
است و اين افزايش در سويه جهشيافته بيشتر قابل رويت است.
محيط كشت سنجش شد. بدين منظور مقدارى از محيط كشت

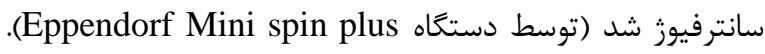
سيس مايع رويى حاصل، به عنوان نمونه برداشته شد. نمونهها

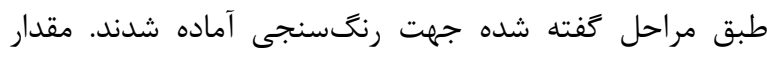

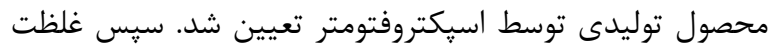

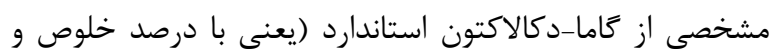

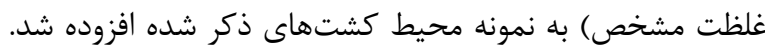

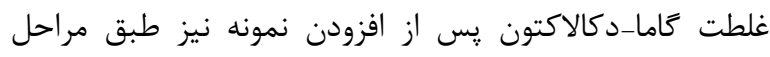

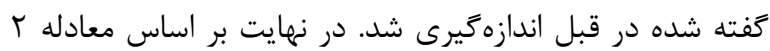

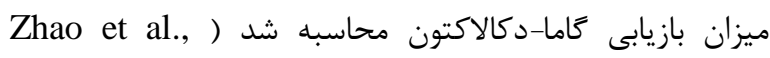

\section{معادله}

GDL sample recovery $(\%)=\frac{w_{a}-w_{a}}{w_{r}} \times 100$

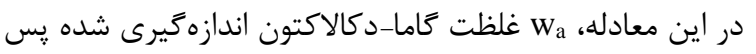

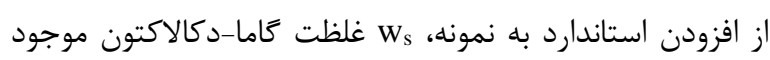

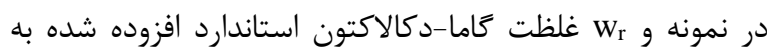
نمونه است.

بررسى تاثير زمان كشت و غلظت روغن كرجك بر ميزان توليد كاما-دكالاكتون براى بررسى ميزان تحمل سويههاى مورد استفاده به غلظت دالات

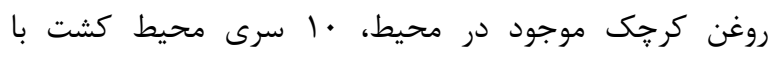

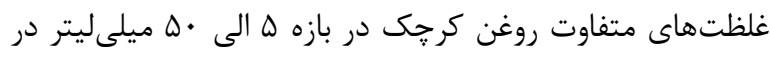

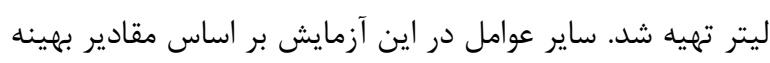

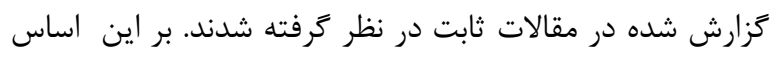

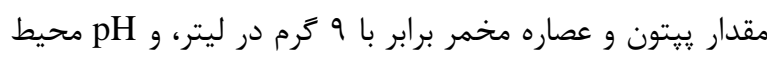
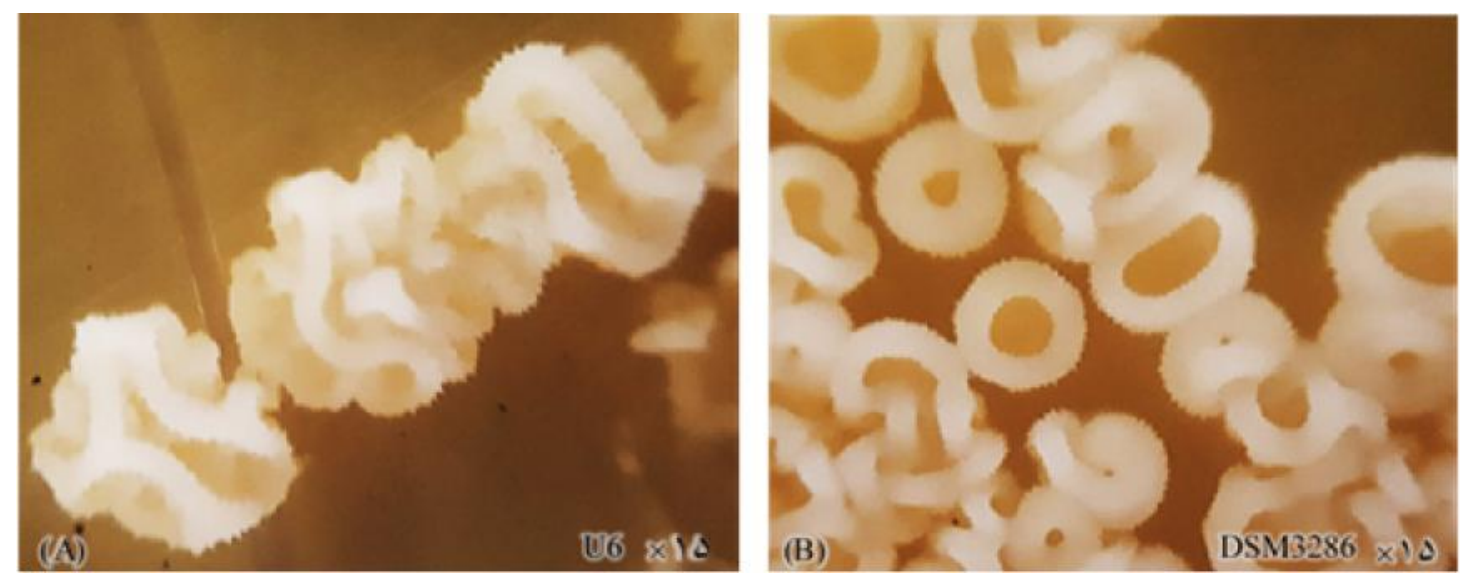

شكل ا- مقايسه كلنىهاى مخمر Marrowia lipolytica طبيعى DSM3286 با سويه جهشيافته U6. دو سويه بر روى يك يليت در شرايط يكسان رشد

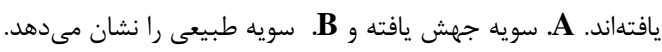

Figure 1. Comparison of wild Yarrowia lipolytica yeast colonies DSM3286 with those of U6 mutant strain. The both strains are grown on the same plate under the same conditions. A. Mutant strain U6 and B. Wild type DSM3286. 


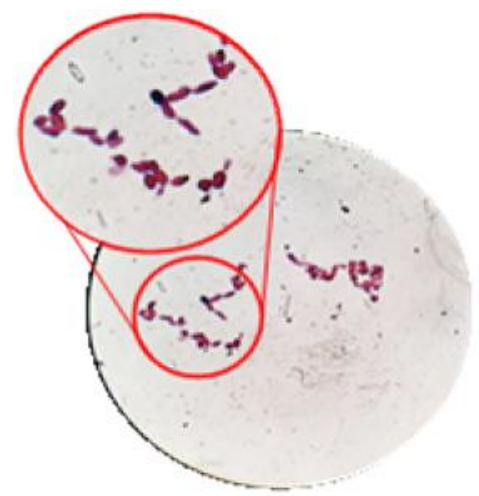

(A)

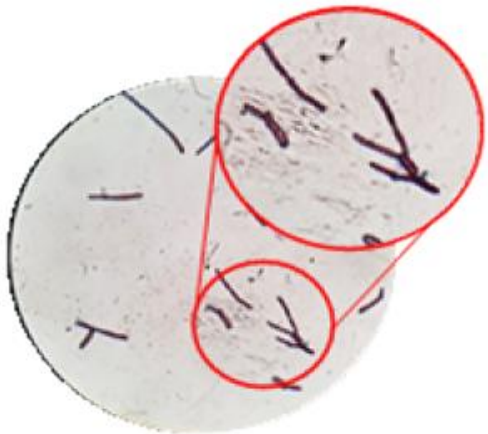

(B)

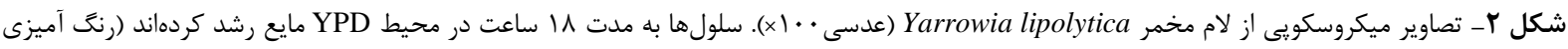

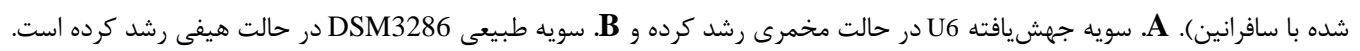

Figure 2. Microscopic images of the slide of Yarrowia lipolytica (100x lens). Cells were grown in liquid YPD medium (stained with safranin) for $18 \mathrm{~h}$. A. The mutant strain U6 grew into yeast-like form. B. The wild strain DSM3286 grew into the hyphae-like form.

(A)
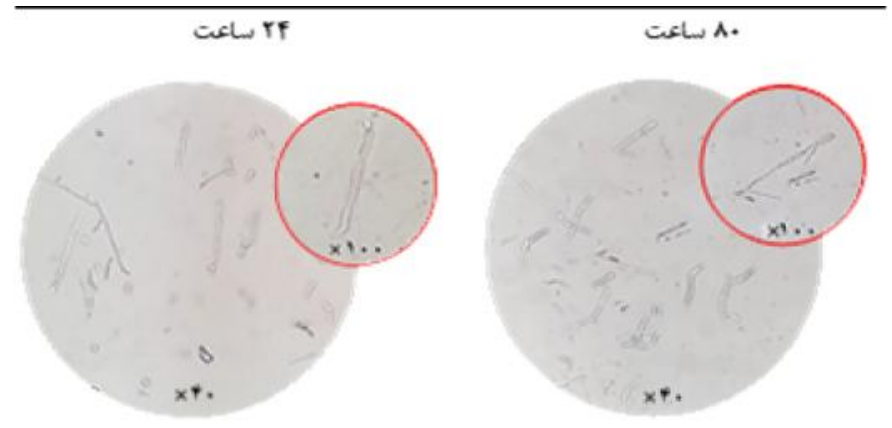

(B)
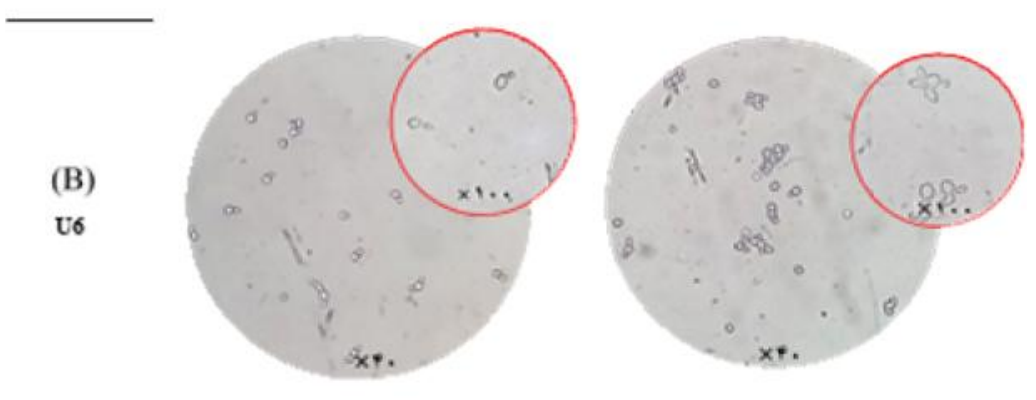

شكل r- مقايسه مورفولوزى سلولهاى مخمر Yarrowia lipolytica طبيعى DSM3286 و جهش يافته U6 رشد كرده درون محيط تبديلزيستى، در

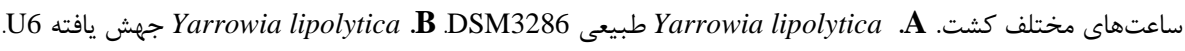

Figure 3. Comparison of the morphology of wild Yarrowia lipolytica DSM3286 cells and U6 mutant yeast cells grown in the biotransformation medium, cultured for different hours (24h and $80 \mathrm{~h})$. A. Wild strain of Yarrowia lipolytica DSM3286. B. Mutant strain of Yarrowia lipolytica U6.

$$
\begin{aligned}
& \text { يس از تهيه سرى رقت، نمونهبردارى و رنغسنجى از هر يك اساس مقادير جذبى رسم شد. معادله حاصل از ركراسيون خطى }
\end{aligned}
$$

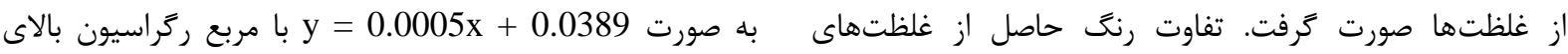

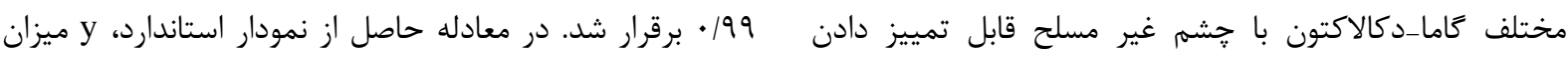

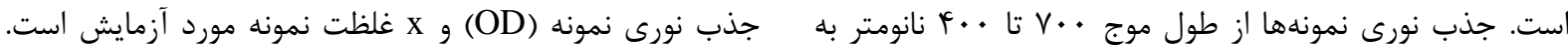

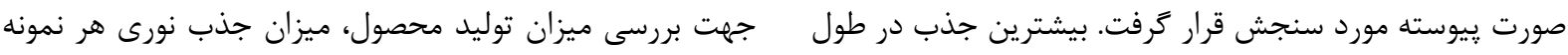

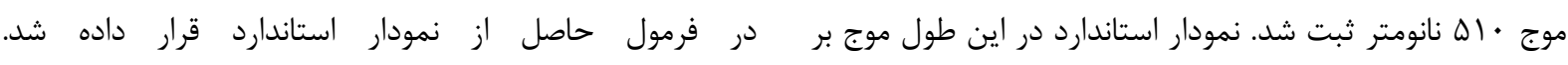


جدول ا- درصد بازيابى كاما-دكالاكتون از نمونهاى كشت ميكروبى.

Table 1. Percentage of gamma-Decalactone recovery from microbial culture samples.

\begin{tabular}{|c|c|c|c|}
\hline Sample GDL ${ }^{*}(\mathrm{~g} / \mathrm{L})$ & $\begin{array}{c}\text { GDL added } \\
(\mathrm{g} / \mathrm{L})\end{array}$ & GDL recovered $(\mathrm{g} / \mathrm{L})$ & Mean recovery $(\%)$ \\
\hline \multirow[t]{3}{*}{0.063} & 0.05 & 0.11 & 94 \\
\hline & 0.1 & 0.17 & 107 \\
\hline & 0.2 & 0.25 & 93.5 \\
\hline \multirow[t]{3}{*}{0.11} & 0.05 & 0.16 & 100 \\
\hline & 0.1 & 0.21 & 100 \\
\hline & 0.2 & 0.32 & 105 \\
\hline \multirow[t]{3}{*}{0.058} & 0.05 & 0.11 & 104 \\
\hline & 0.1 & 0.15 & 92 \\
\hline & 0.2 & 0.25 & 96 \\
\hline
\end{tabular}

"GDL: gamma-Decalactone

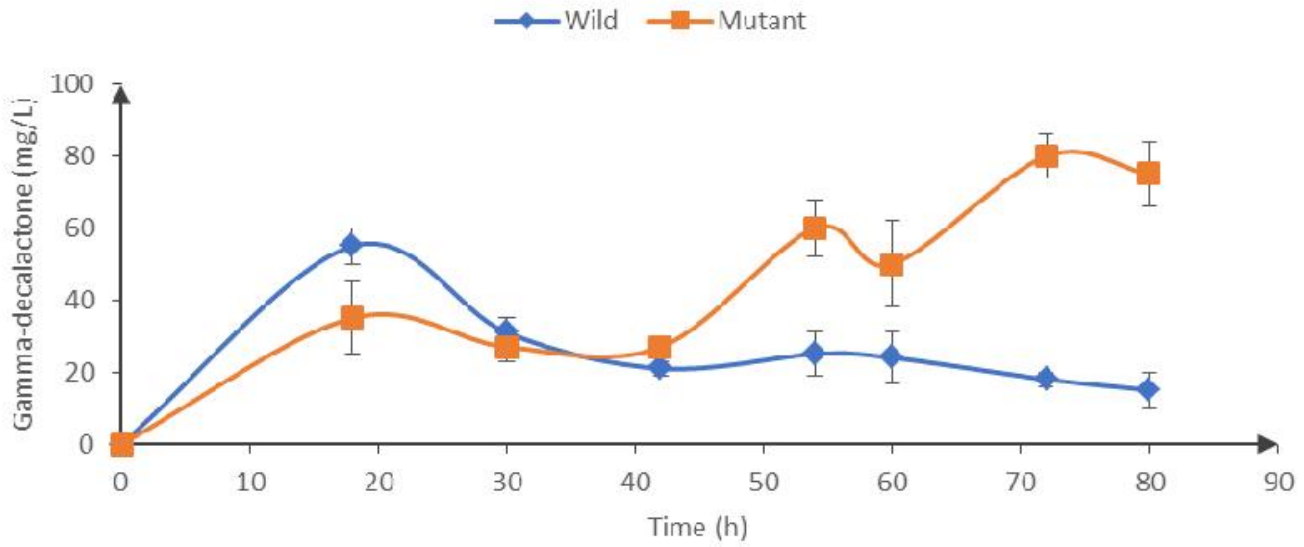

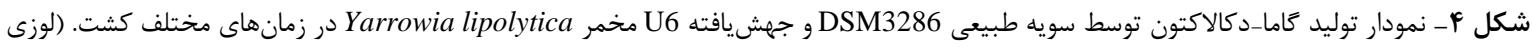

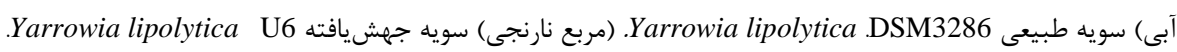

Figure 4. Diagram of gamma-Decalactone production by wild strain DSM3286 (Blue rhombus) and U6 mutant of Yarrowia lipolytica (Orange Square) cultured for different times.

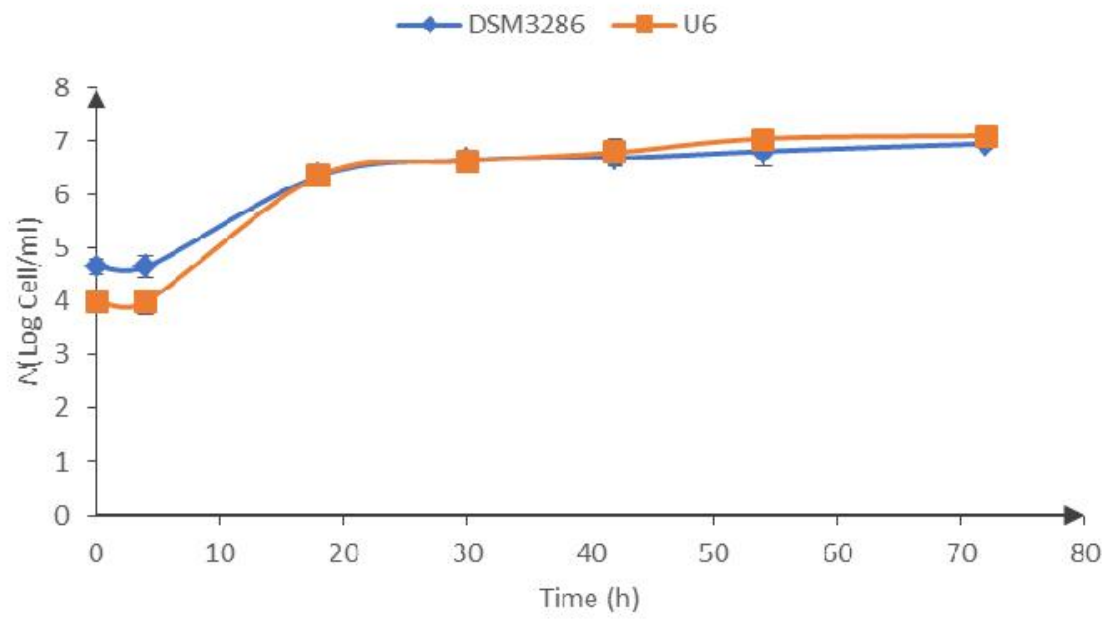

شكل ه- منحنى رشد سلولهاى طبيعى DSM3286 و جهشيافته مخمر Yarrowia lipolytica U6 در محيط تبديل زيستى. (لوزى آبى) سويه طبيعى

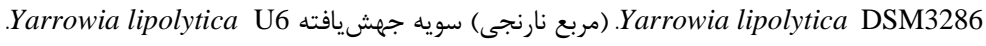

Figure 5. Growth curve of wild DSM3286 (Blue rhombus) and mutant U6 strains (Orange Square) of Yarrowia lipolytica in biotransformation medium. 
با محاسبه شيب خط نمودار حاصل، سرعت ويزه رشد به دست

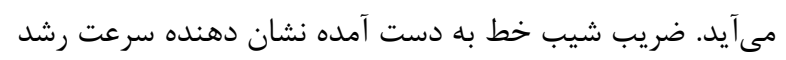

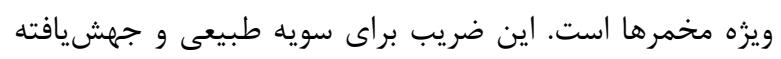

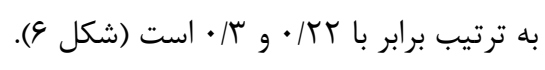

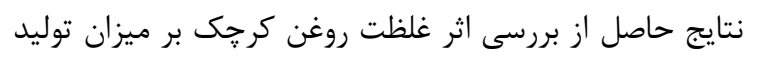

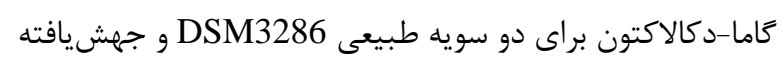

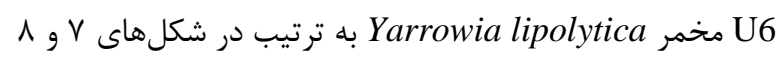

$$
\text { آورده شده است. }
$$

با توجه به شكل V در سوريه طبيعى بيست ساعت يس از

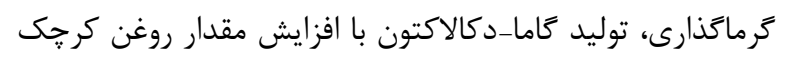

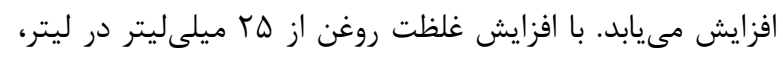
توليد محصول با شيب بيشترى افزايش ييدا مى كند ولى در بازه

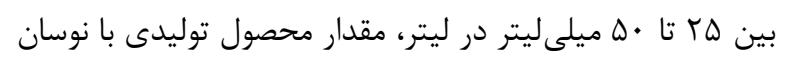

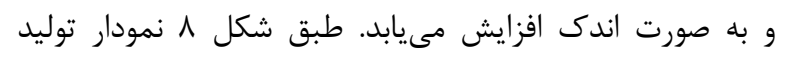
محصول براى سويه جهش يافته U6 در ساعات اوليه كشت،

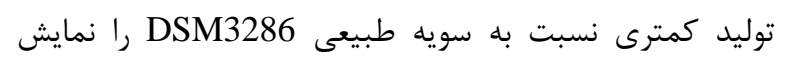

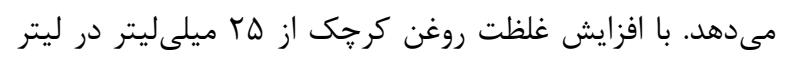
مقدار محصول توليدى با شيب بيشترى افزايش ميى ميابد ولى بـ

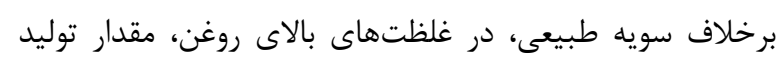

$$
\text { محصول كاهش مىيابد. }
$$

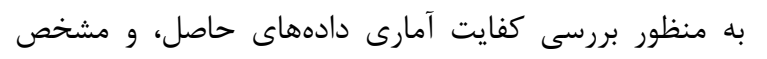
شدن بهينهترين رابطه بين زمان كشت و غلظت روغن، دانه دادها توسط نرمافزار

$$
\text { تحليل و بررسى قرار گرفتند (جدول ז، س). }
$$

به منظور مشخص شدن مقدار كاما-دكالاكتون واقعى نمونهها و مقدار قابل سنجش به روش رنتَسنجى، ابتدا غلظت محصول

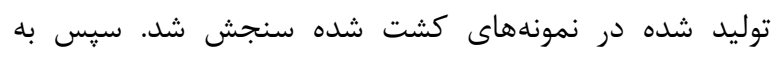
نمونههاى كشت شده غلظت مشخصى از ماما_دكالاكتون استاندارد افزوده شد. در نهايت نمونهها سانترفيوز شده و طبق مراحل ذكر شده در بخشهاى قبل، اقدام به سنجش كاما-

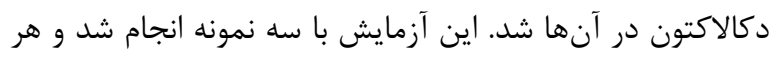
نمونه سه بار مورد سنجش قرار گرفت. ميانگين دادههاى حاصل در جدول ا آورده شده است. درصد بازيابى با قرار دادن مقادير

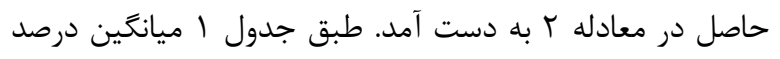
بازيابى كاما-دكالاكتون از نمونهها برابر 99 درصد باصا انحراف معيار ه/ ه است.

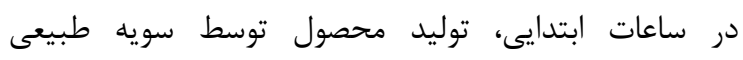

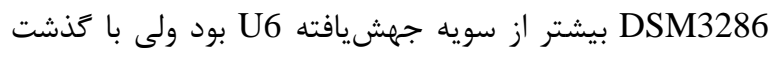

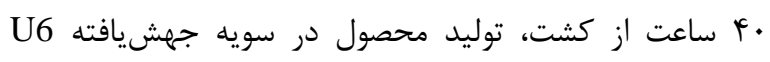

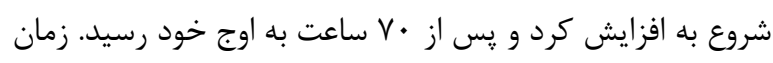

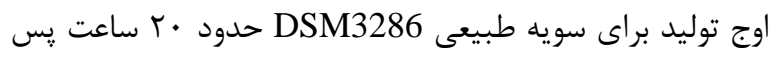

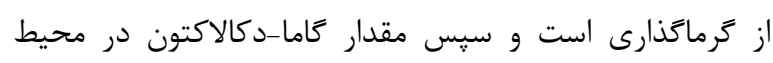
كشت شروع به كاهش ميىنمايد ( شكل عأ).

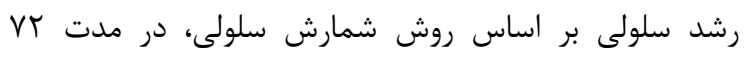

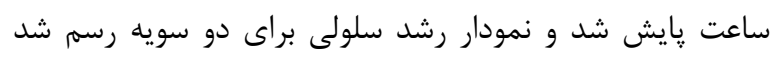

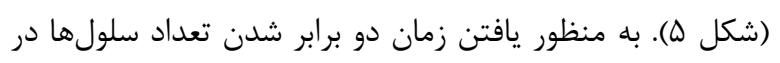

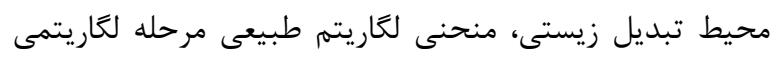
رشد رسم شد.

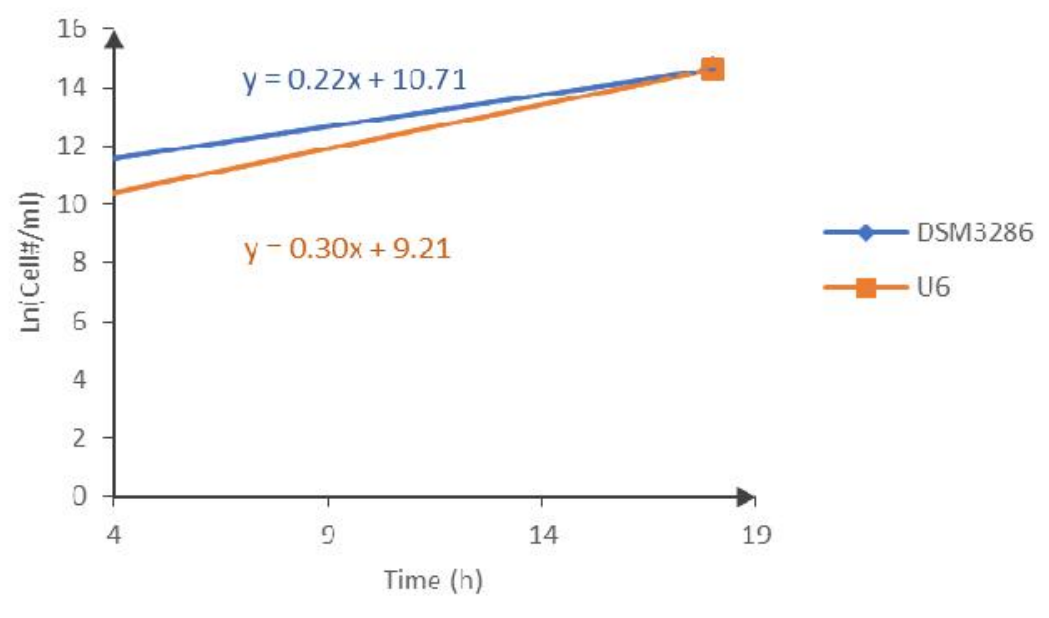

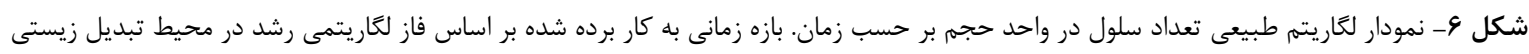

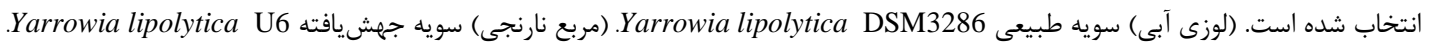

Figure 6. Natural logarithm diagram of the number of cells per unit volume by time for wild DSM3286 (Blue rhombus) and mutant U6 strains (Orange Square) of Yarrowia lipolytica. The time interval used is selected based on the logarithmic phase of growth in the biotransformation environment. 


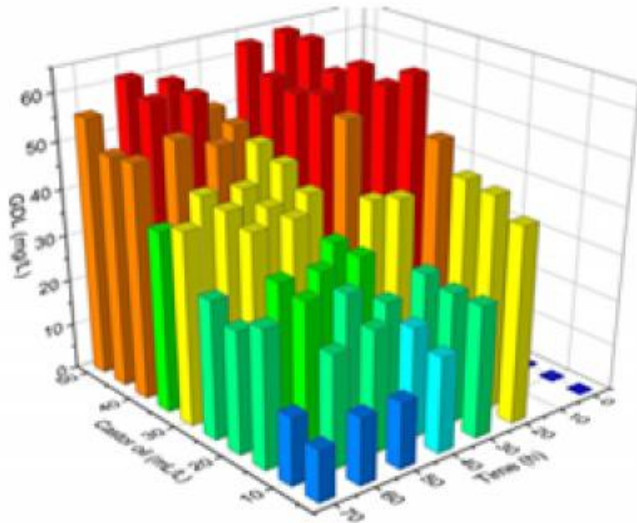

(A)

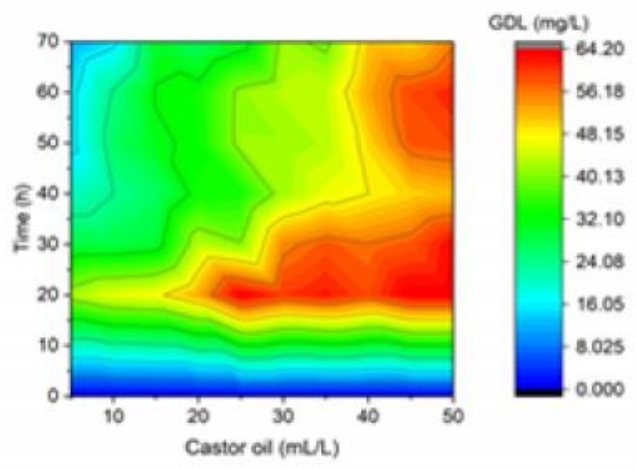

(B)

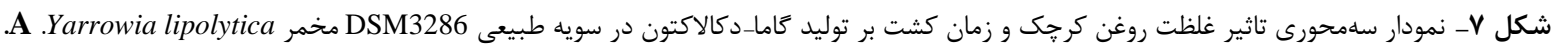
نمودار ستونى. B. نماى كانتور.

Figure 7. Three-axis diagram of the effect of castor oil concentration and culture time on gamma-Decalactone production in natural strain DSM3286 yeast Yarrowia lipolytica. A. Bar chart. B. Contour view.

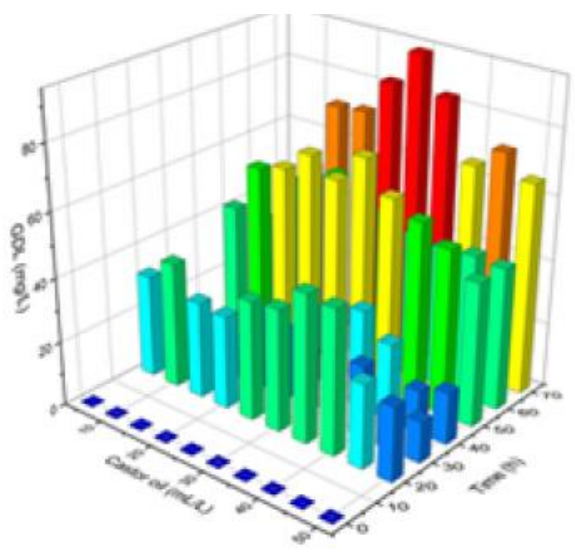

(A)

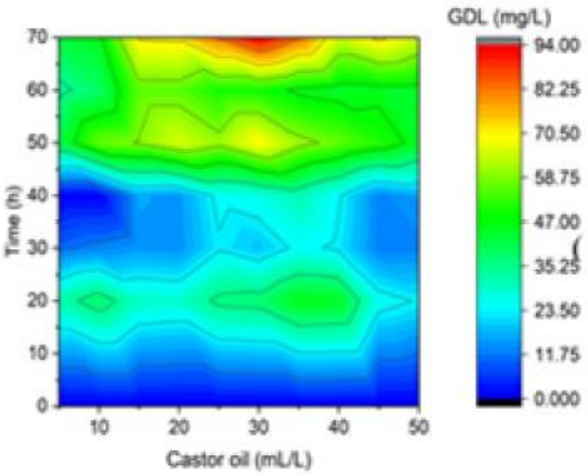

(B)

شكل ^- نمودار سهمحورى تاثير غلظت روغن كرجك و زمان كشت بر توليد كاما-دكالاكتون در سويه جهش يافته U6 مخمر Yarrowia lipolytica. نمودار ستونى. B. B. شماى كانتور.

Figure 8. Three-axis diagram of the effect of castor oil concentration and culture time on gamma-Decalactone production in the U6 mutant strain of Yarrowia lipolytica. A. Bar chart. B. Contour view.

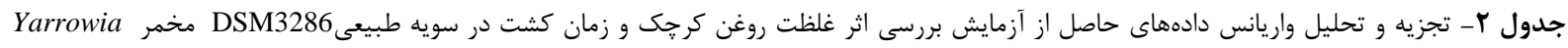
lipolytica

Table 2. Analysis of variance of experimental data Investigation of the effect of castor oil concentration and culture time in natural strain DSM3286 yeast Yarrowia lipolytica on the production yield.

\begin{tabular}{ccccccc}
\hline Factor & Sum of squares & Degree of Freedoms & Mean square & F-value & p-value & \\
\hline Model & 11355.25 & 14 & 811.09 & 44.84 & $<0.0001$ & Significant \\
Castor oil & 8451.77 & 9 & 939.09 & 51.91 & $<0.0001$ & \\
Time & 2903.48 & 5 & 580.70 & 32.10 & $<0.0001$ & \\
Residue & 814.06 & 45 & 18.09 & & & \\
Sum & 12169.32 & 59 & & & & \\
\hline
\end{tabular}




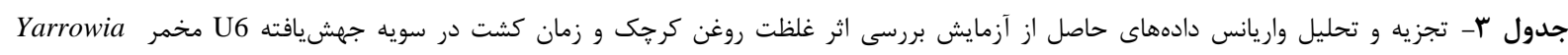
lipolytica

Table 3. Analysis of variance of experimental data Investigation of the effect of castor oil concentration and culture time in U6 mutant strain Yarrowia lipolytica on the production yield.

\begin{tabular}{ccccccc}
\hline Factor & Sum of squares & Degree of Freedoms & Mean square & F-value & p-value & \\
\hline Model & 25876.52 & 14 & 1848.32 & 37.89 & $<0.0001$ & Significant \\
Castor oil & 2995.73 & 9 & 332.86 & 6.82 & $<0.0001$ & \\
Time & 22880.79 & 5 & 4576.16 & 93.82 & $<0.0001$ & \\
Residue & 2194.95 & 45 & 48.78 & & & \\
Sum & 28071.47 & 59 & & & & \\
\hline
\end{tabular}

مضاعف شده بود باريكتر ديده مىشوند. در حالى كه مخمرهاى

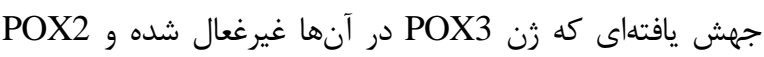
بيان مضاعف شده بود، بزرگتر ديده مىشدند. اين تغيير ابعاد احتمالا به دليل تجمع اجسام جربى رخ ميدهد ) Beopoulos et

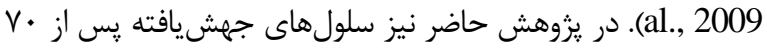

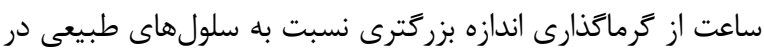

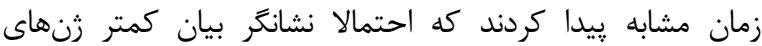
نسبت به ساير اكسيدازها در سويه جهشيافته باشد. محققان با حذف زنهاى POX2 و POX3 در سويه W29 مخمر Yarrowia lipolytica، متوجه شدند كه توليد محصول نسبت به سويه طبيعى در ساعات ابتدايى كشت كمتر بوده ولى קس از حذشت • V ساعت، بيش از دو برابر محصول بيشترى توليد شده است (Waché et al., 2001). اين احتمال وجود دارد كه در سويه U6 بر اثر جهش، زنهاى POX نيز دجار جهش شده باشند. همجنين محققين با مقايسه توليد كامادكالاكتون توسط سلولهاى هيفى شكل و مخمرى شكل كزارش دادند كه در حالت مخدمرى توليد محصول نسبت به حالت هيفى ديرتر به اوج خود مىرسد ولى مقدار محصول توليدى بيشتر است (Braga et al., 2015).

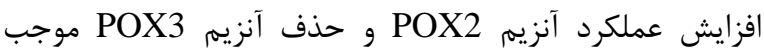

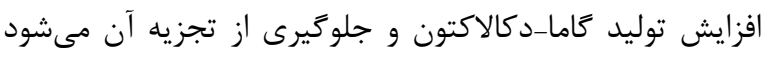
(Beopoulos et al., 2009)، اين موضوع مىتواند با توليد محصول بيشتر توسط سويه جهشيافته نسبت به سويه طبيعى در يزوهش حاضر تا حدودى تاييد شود.

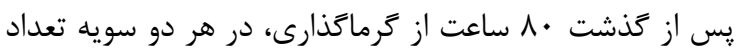
جوانهجانبى متصل به سلول مادر افزايش ييدا كرده است و اين افزايش در سويه جهشيافته بيشتر قابل رويت است. وجود مقادير بالاى اسيد ريسينولئيك (ماده اصلى تشكيل دهنده روغن رين كرجى) در محيط كشت مخمرها موجب رشد قطبى جوانها و

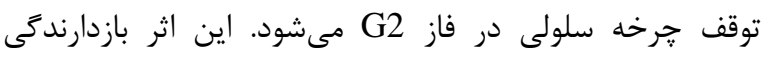

در سلولهاى طبيعى، ريختشناسى كلنىها مىتواند تحت تاثير زنتيك و شرايط محيطى از حالت صاف و براق تا زبر و مات تغيير يابد كه در اين مورد احتمالا به علت تغييرات زنتيكى حاصئ حاصل از از جهشزايى با يرتو فرا بنفش، ريختشناسى كلنىهاى سويه تحت تاثير قرار گرفته است (Darvishi, 2014). طبق مطالعات صورت كرفته وجود منابع كربنى مانند كلوكز، سيترات و اسيدهاى جرب در محيط كشت مخمر lipolytica (Ruiz-Herrera \& Sentandreu, 2002) اين يروهش براى سويه طبيعى مطابقت دارد. اما سويه جهش يافته در هر دو محيط كشت روغنى و كلوكز دار، تشكيل هيف نداد.

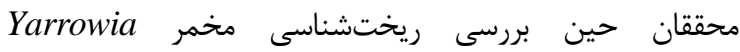

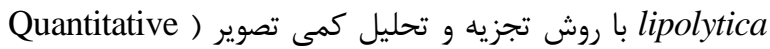

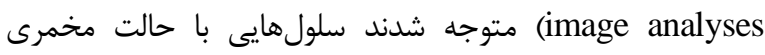
مانند، بيشتر از سلولهاى هيفى شكل، كاما_دكالاكتون توليد مى كنند. آنها به اين منظور با تغيير شرايط محيطى (از قبيل در دسترس قرار دادن كلوكز) حالت هيفى را در سلولها مان القا كرده و

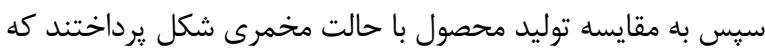

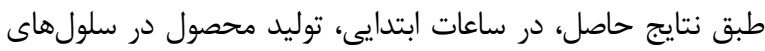
هيفى كمى بيشتر بوده ولى زِ از • ها ساعت از كشت، توليد

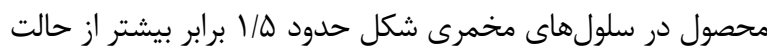
هيفى شده بود (Braga et al., 2015). در يزوهش حسو حاضر نيز توليد محصول در سويه جهشيافته مخمرى شكل بيشتر از سويه طبيعى هيفى شكل است. همجنين زمان اوج توليد محصول در سويه جهشيافته مخمرى شكل بيشتر از سويه طبيعى هيفى شكل است ( شكل ع)، كه با نتايج يزوهش حاضر مطابقت دارد.

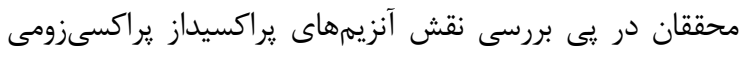

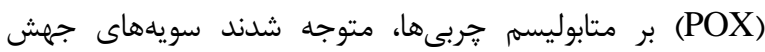
يافتهاى كه زن POX2 در آنها غيرفعال شده و POX3 بيان 
بين غلظت روغن كرجك و توليد گاما-دكالاكتون رابطه مستقيم

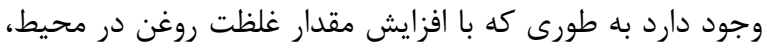
توليد محصول نيز افزايش مى يابد. اين تيم مقدار • ب كرم در ليتر

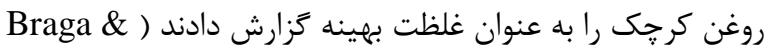

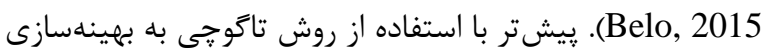
مقدار توليد كاما-دكالاكتون اقدام شده است كه نتايج حاصل

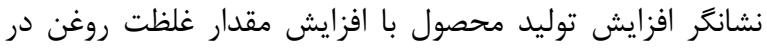
محيط است. در مطالعه مذبور به بررسى اثر مقادير بيشتر روغن

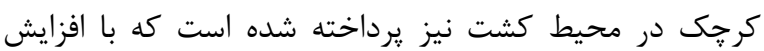

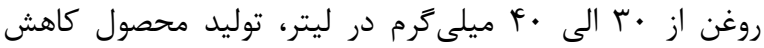

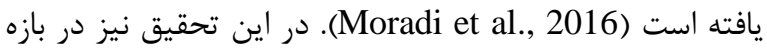

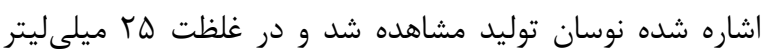
روغن در يك ليتر محيط كشت، افزايش توليد نسبت به نقاط همجوار مشاهده مىشود كه با نتايج مطالعه مذبور مطابقت دارد.

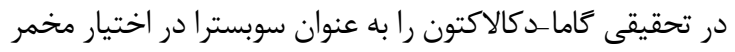
Yarrowia lipolytica قادر به مصرف اين ماده به عنوان منبع كربن هستند ( Aguedo et

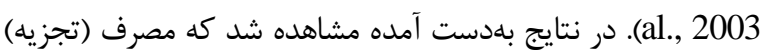
كاما_دكالاكتون در ساعات بعدى كرماكذارى، با افزايش روغن كاهش يافت، احتمالا اين بديده به علت خاصيت حفاظتى روغن از

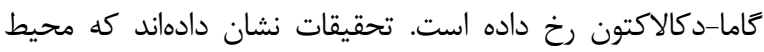
دوفازى (آب و روغن) موجب كاهش اثر سمى لاكتونها بر روى دادي سلولها و همجنين كاهش مصرف لاكتون به وسيله سلول مى كرددد. در واقع به نظر مىرسد، لاكتون در فاز روغنى مخلوط شده و از از دسترس سلول خارج مىشود (Ta et al., 2010). نمودار توليد محصول براى سويه جهش يافته U6 در ساعات اوليه

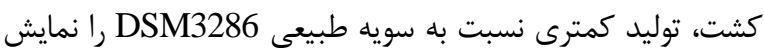

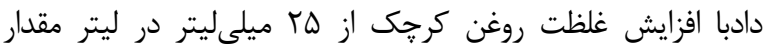
محصول توليدى با شيب بيشترى افزايش يافت ولى برخلاف سويه طبيعى، در غلظتهاى بالاى روغن، مقدار توليد محصول كاهش يافت.

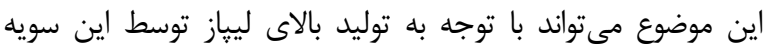

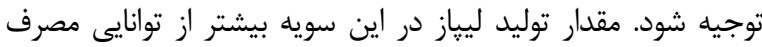

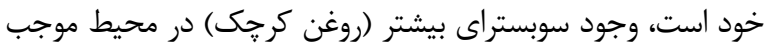
افزايش فعاليت اين آنزيم شده كه در نتيجه اسيد ريسينولئيك بيشترى در محيط توليد شده است. اسيدهاى خرب (ماند اسيد

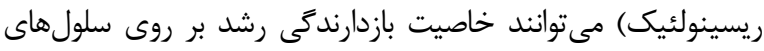
مخمرى داشته باشند (Lee et al., 1998). نمودار توليد محصول در سويه جهشيافته U6 با كذشت زمان كشت، دجار افزايش و كاهش شده و حالتى شبيه به نمودارهاى

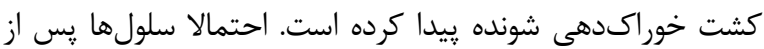

احتمالا به دليل تاثير اين ماده بر روى سيخنالهاى كلسيمى رجئ

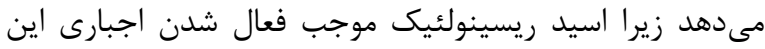

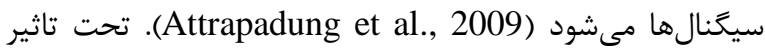
ليياز خارج سلولى مخمر Yarrowia lipolytica بر روى روغن

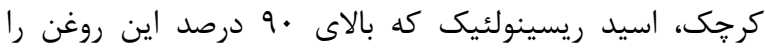
تشكيل داده است در محيط آزاد مى شود. بنابراين هر خه از زماني

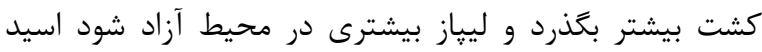

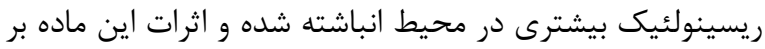
سلولها بيشتر ديده مىشود. اين موضوع مىتواند علت تغييرات

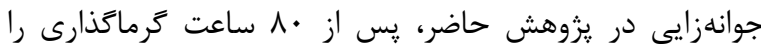
مشخص نمايد. با توجه به نتايج بهدست آمده، ميانگين درصدهاى بازيابى Fاما-دكالاكتون از محيط كشت مورد استفاده در اين تحقيق، بالاى 99 درصد است كه نشانكر قابل قبول بودن نتايج حاصل از از دان

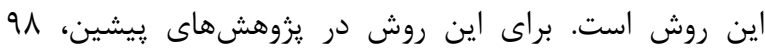
درصد بازيابى كزارش شده است (Zhao et al., 2014). نمودار حاصل براى توليد محصول توسط سويه طبئى نائى

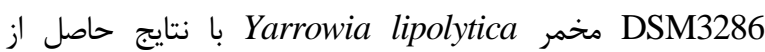
يزوهشهاى يِيشين براى همين سويه كه در شرايط بيوراكتور

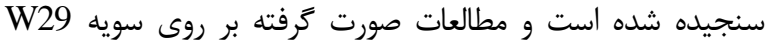

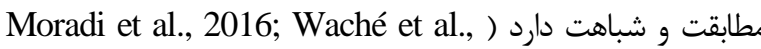
2001). با اين حال در مطالعه ديخرى •01 ساعت يس از كشت، به عنوان زمان بيشينه توليد سويه W29 مخمر Sarrowia lipolytica كزارش شده است (Braga et al., 2012). در محيط حاوى روغن كرجك، سويه جهشيافته سرعت رشد بيشترى نسبت به سويه طبيعى داشت. بيشتر بودن سرعت رشد

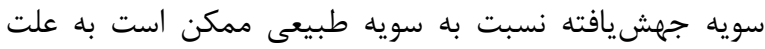
عدم تشكيل هيف در سويه جهشيافته رخ داده باشد. تغيير در سرعت رشد اركانيسمها مىتواند دلايل مختلفى داشته باشد. به دانه

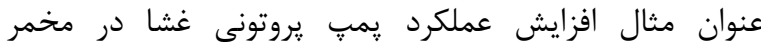
Yarrowia lipolytica مخمر باشد (Portillo \& Serrano, 1989).

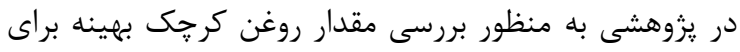

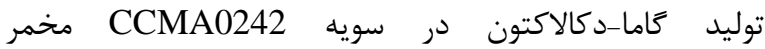
Yarrowia lipolytica

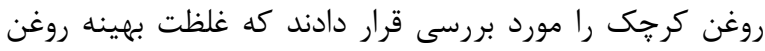

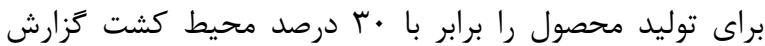

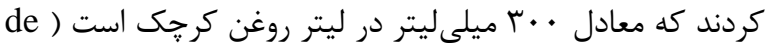
Andrade et al., 2017 مخمر Yarrowia lipolytica صورت گرفته، مشخص شده است دم 


\section{REFERENCES}

Aguedo, M., Beney, L., Waché, Y. \& Belin, J.M. 2003. Mechanisms underlying the toxicity of lactone aroma compounds towards the producing yeast cells. Journal of Applied Microbiology 94: 258-265.

Arctander, S. 1969. Perfume and flavor chemicals: Aroma chemicals (Vol. 2). Allured Publishing Corporation, Carol Stream. pp:31-170.

Attrapadung, S., Yoshida, J., Kimura, K.i., Mizunuma, M., Miyakawa, T. \& Thanomsub, B.W. 2009. Identification of ricinoleic acid as an inhibitor of $\mathrm{Ca} 2+$ signal-mediated cell-cycle regulation in budding yeast. FEMS Yeast Research 10: $38-43$.

Beopoulos, A., Chardot, T. \& Nicaud, J.M. 2009. Yarrowia lipolytica: A model and a tool to understand the mechanisms implicated in lipid accumulation. Biochimie 91: 692-696.

Berger, R. G. 2007. Flavours and fragrances: chemistry, bioprocessing and sustainability. Springer Science \& Business Media, Berlin. pp: 1-86.

Braga, A. \& Belo, I. 2015. Production of $\gamma$-decalactone by Yarrowia lipolytica: insights into experimental conditions and operating mode optimization. Journal of Chemical Technology \& Biotechnology 90: 559565.

Braga, A. \& Belo, I. 2016. Biotechnological production of $\gamma$-decalactone, a peach like aroma, by Yarrowia lipolytica. World Journal of Microbiology and Biotechnology 32: 169.

Braga, A., Gomes, N. \& Belo, I. 2012. Lipase induction in Yarrowia lipolytica for castor oil hydrolysis and its effect on $\gamma$-decalactone production. Journal of the American Oil Chemists' Society 89: 1041-1047.

Braga, A., Mesquita, D., Amaral, A., Ferreira, E. \& Belo, I. 2015. Quantitative image analysis as a tool for Yarrowia lipolytica dimorphic growth evaluation in different culture media. Journal of Biotechnology 217: $22-30$.

Braga, A. C. 2014. Strategies for increasing aroma production from castor oil by Yarrowia lipolytica. Doctoral dissertation, University of Minho. Portugal.

Darvishi, F. 2014. Biotechnological applications of the yeast Yarrowia lipolytica. Springer, New York, 77 pp.

Darvishi, F., Ariana, M., Marella, E. R. \& Borodina, I. 2018. Advances in synthetic biology of oleaginous yeast Yarrowia lipolytica for producing non-native chemicals. Applied microbiology and biotechnology 102: 5925-5938.

Darvishi, F. \& Chen, H. 2018. Microbial Biotechnology: Progress and Trends. CRC Press, Florida, 380 pp.

Darvishi, F., Destain, J., Nahvi, I., Thonart, P. \& Zarkesh-Esfahani, H. 2011. High-level production of extracellular lipase by Yarrowia lipolytica mutants from methyl oleate. New Biotechnology 28: 756-760.

Darvishi, F., Nahvi, I., Zarkesh-Esfahani, H. \& Momenbeik, F. 2009. Effect of plant oils upon lipase and citric acid production in Yarrowia lipolytica yeast. BioMed Research International 2009: 10411047.
آن كه لاكتون توليدى به آستانه تحمل نزديك مىشود، با فعالسازى كئر

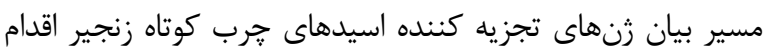
به تجزيه و مصرف آن مى كنند. يّ از كاز كاهش مقدار لاكتون، مجدد

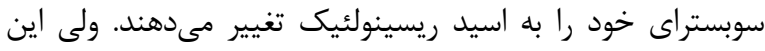

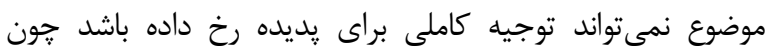

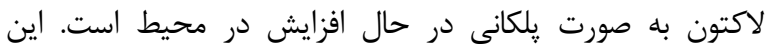

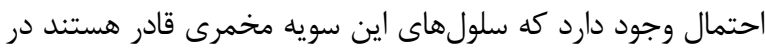

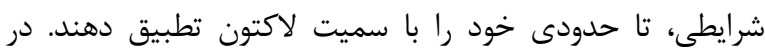

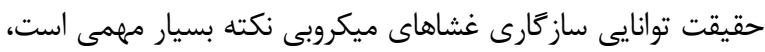

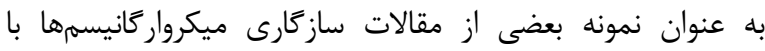

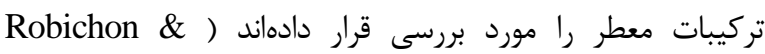

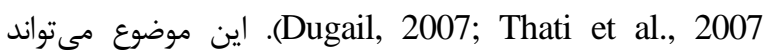
زمينهساز تحقيقات آينده در زمينه تكامل تطبيقى آزمايشگاهى

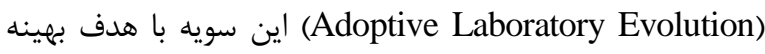
سازى توليد لاكتونها باشد. نتايج حاصل از تحليل ANOVA نشاندهنده معنىدار بودن

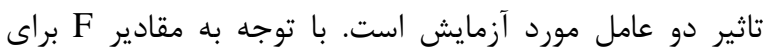

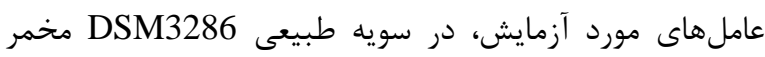
Yarrowia lipolytica محصول بيشتر از زمان كشت است و در سويه جهشيافته مقدار F براى عامل روغن كرجى بيشت بيشتر است.

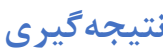

بر اساس نتايج به دست آمده از اين تحقيق، سلولهايى با

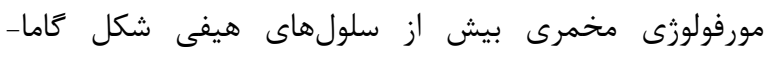

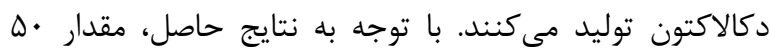

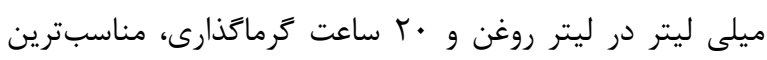

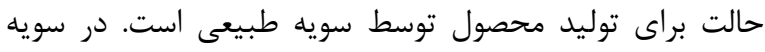

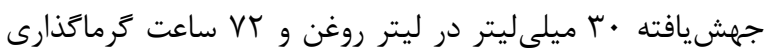

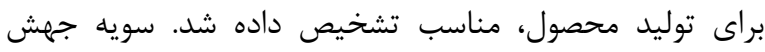

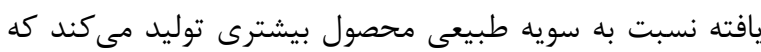

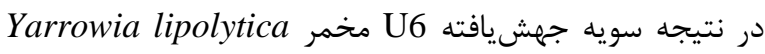
به منظور توليد كاما-دكالاكتون مناسبتر تشخيص دافئ داده شد.

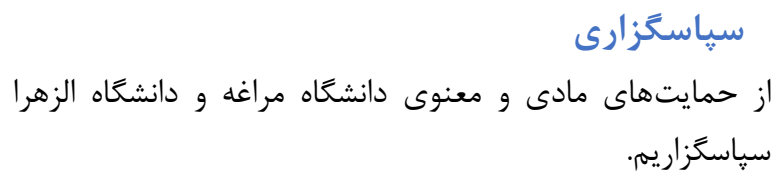


de Andrade, D. P., Ferreira Carvalho, B., Freitas Schwan, R. \& Ribeiro Dias, D. 2017. Production of $\gamma$-Decalactone by Yeast Strains under Different Conditions. Food Technology and Biotechnology 55: 225-230.

Farbood, M., \& Willis, B. 1985. Production of gammadecalactone (U.S. Patent No. 4, 560, 656). Gatfield, I. L. 1988. Production of flavor and aroma compounds by biotechnology. Food Technology 42: 169.

Kawasse, F.M., Amaral, P.F., Rocha-Leão, M.H. M., Amaral, A., Ferreira, E. \& Coelho, M. 2003. Morphological analysis of Yarrowia lipolytica under stress conditions through image processing. Bioprocess and Biosystems Engineering 25: 371-375.

Lee, S.-L., Cheng, H.-Y., Chen, W.C. \& Chou, C.C. 1998. Production of $\gamma$-decalactone from ricinoleic acid by immobilized cells of Sporidiobolus salmonicolor. Process Biochemistry 33: 453-459.

Liese, A., Seelbach, K. \& Wandrey, C. 2006. Industrial biotransformations. John Wiley \& Sons, New Jersey, 570pp.

Liu, Z., Moradi, H., Shi, S. \& Darvishi, F. 2021. Yeasts as microbial cell factories for sustainable production of biofuels. Renewable and Sustainable Energy Reviews 143: 110907.

Maga, J. A. \& Katz, I. 1976. Lactones in foods. Critical Reviews in Food Science \& Nutrition 8: 1-56.

Malajowicz, J., Nowak, D., Fabiszewska, A. \& Iuliano, A. 2020. Comparison of gamma-decalactone biosynthesis by yeast Yarrowia lipolytica MTLY40$2 \mathrm{p}$ and W29 in batch-cultures. Biotechnology \& Biotechnological Equipment 34: 330-340.

Marsafari, M., Samizadeh, H., Rabiei1, B., Ashraf Mehrabi, A., Lv, Y. \& Xu, P. 2020. The optimization of Naringenin biosynthesis pathway using Yarrowia lipolytica cell culture. Nova Biologica Reperta 7: 133-144. (In Persian).

Mather, J. P. \& Roberts, P. E. 1998. Introduction to cell and tissue culture: theory and technique (1 ed.). Springer Science \& Business Media, Berlin, 250 pp.

Moradi, H. Asadollahi, M. A., \& Nahvi, I. 2016. Optimaztion of gamma-decalactone production by yeast Yarrowia lipolytica using the taguchi method. Journal of Microbiology, Biotechnology \& Food Sciences 6: 684-689.

Okui, S., Uchiyama, M., Mizugaki, M. \& Sugawara, A. 1963. Intermediates of the oxidative breakdown of ricinoleic acid by Candida genus. Biochimica et
Biophysica Acta 70: 346-348.

Portillo, F. \& Serrano, R. 1989. Growth control strength and active site of yeast plasma membrane ATPase studied by site-directed mutagenesis. European Journal of Biochemistry 186: 501-507.

Robichon, C. \& Dugail, I. 2007. De novo cholesterol synthesis at the crossroads of adaptive response to extracellular stress through SREBP. Biochimie 89: 260-264.

Ruiz-Herrera, J. \& Sentandreu, R. 2002. Different effectors of dimorphism in Yarrowia lipolytica. Archives of Microbiology 178: 477-483.

Siek, T., Albin, I., Sather, L. \& Lindsay, R. 1971. Comparison of flavor thresholds of aliphatic lactones with those of fatty acids, esters, aldehydes, alcohols, and ketones. Journal of Dairy Science 54: 1-4.

Ta, T. M. N., Cao-Hoang, L., Phan-Thi, H., Tran, H. D., Souffou, N., Gresti, J., Marechal, P.A., Cavin, J.F. \& Waché, Y. 2010. New insights into the effect of medium-chain-length lactones on yeast membranes. Importance of the culture medium. Applied microbiology and biotechnology 87: 10891099.

Thati, B., Noble, A., Rowan, R., Creaven, B.S., Walsh, M., McCann, M., Egan, D. \& Kavanagh, K. 2007. Mechanism of action of coumarin and silver (I)coumarin complexes against the pathogenic yeast Candida albicans. Toxicology in Vitro 21: 801-808.

Vandamme, E. J. 2003. Bioflavours and fragrances via fungi and their enzymes. Fungal Diversity 13: 153166.

Waché, Y., Aguedo, M., Choquet, A., Gatfield, I.L., Nicaud, J.-M. \& Belin, J.M. 2001. Role of $\beta$ oxidation enzymes in $\gamma$-decalactone production by the yeast Yarrowia lipolytica. Applied and Environmental Microbiology 67: 5700-5704.

Zeng, W., Du, G., Chen, J., Li, J. \& Zhou, J. 2015. A high-throughput screening procedure for enhancing $\alpha$ ketoglutaric acid production in Yarrowia lipolytica by random mutagenesis. Process Biochemistry 50: 15161522.

Zhao, Y., Mu, X., Nie, Y. \& Xu, Y. 2014. A new rapid spectrophotometric quantitative determination method for $\gamma$-decalactone and application in high throughput screening for $\gamma$-decalactone producing strains. Food Science and Biotechnology 23: 1935-1940.

How to cite this article:

Darvishi, F. \& Kheirollahi Meidani, A. 2021. Comparison of gamma-decalactone production in wild-type and mutant strains of Yarrowia lipolytica. Nova Biologica Reperta 8: 183-194. (In Persian).

درويشى، ف. و خير اللهى ميدانى، آ. .. 1F. مقايسه توليد Fاما-دكالاكتون در سويه طبيعى و جهش يافته مخمر Yarrowia lipolytica. يافتههاى نوين در

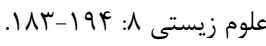

